\title{
Power-Sharing Challenges: From Weak Adoptability to Dysfunction in Iraq
}

Joanne McEvoy (University of Aberdeen, UK) and Eduardo Wassim Aboultaif (Holy Spirit University of Kaslik, Lebanon)

\begin{abstract}
A potentially beneficial conflict management tool, post-conflict power-sharing is often marred by political crises and instability. We explore the link between power-sharing 'adoptability' and functionality. Focusing on Iraq, we demonstrate that weak adoptability (when one of more groups have grave reservations about the settlement) harms power-sharing in several important ways. First, weak adoptability by the Sunni community led to their exclusion and mobilisation against the state. Second, weak adoptability provided political space for Shiites to dominate in politics, undermining the very basis of post-conflict power-sharing. Third, weak adoptability further compounded constitutional contestation, leading to the Kurdish independence referendum in 2017.
\end{abstract}

\section{Introduction}

As protracted conflict resolution efforts from Syria to Yemen remind us, the quest to end war and build democracy in deeply divided, fragile states remains a pressing political problem. In transitional statebuilding processes, power-sharing has emerged as the default set of political institutions to halt violence and enhance prospects for peace. In essence, power-sharing facilitates joint decision-making between the significant groups in society and provides former combatants with guaranteed access to power. A fully inclusive political system is assumed to be more legitimate by providing minorities with assurances they will not be excluded from power, thereby facilitating political stability. Defined by Hartzell and Hoddie (2003, p. 320) power-sharing consists of 'rules that, in addition to defining how decisions will be made by groups within the polity, allocate decision-making rights, including access to state resources, among collectivities competing for power.' Consociational power-sharing entails the adoption of executive power-sharing, proportionality, group autonomy, and mutual veto rights. Powersharing has been an attractive conflict management tool for international mediators as a 
compromise between self-determination and territorial integrity norms in the hope that the new system will improve security and cement democracy and minority rights (McCulloch and McEvoy, 2018). And consociational power sharing is described as 'one of the strongest, widely discussed, and influential research programmes in the field of comparative politics' (Taylor, 2009. p. 1).

Though power-sharing is largely accepted as a leading conflict resolution paradigm, its practical implementation is often hampered by recurring political crises. From Bosnia and Herzegovina to Burundi, Iraq, Lebanon, Northern Ireland and Macedonia, power sharing has encountered serious political challenges emanating from inter-communal disagreements and political wrangling over policy issues and the future configuration of the state. In Northern Ireland, often held up as the exemplar of power sharing given the non-recurrence of large scale violence since the Good Friday Agreement of 1998, the relatively successful political institutions suffered a series of political crises and collapsed in 2017 (finally restored in early 2020). In Burundi, an electoral crisis in 2015 and subsequent failed coup d'état threatened the establishment of a military-dominated, one-party system (Vandeginste, 2015, 2017). In Iraq, where power sharing was a central element of the 2005 Constitution, limited elite cooperation and ongoing violence have had negative consequences for stability. Recent power-sharing scholarship notes the uneven performance of power-sharing across cases and periods; that it 'has enjoyed success in some places but not in others, in some places at particular times, but not at other times, and with respect to some issues but not all' (McGarry, 2020, p.100). Leading proponents of consociationalism also argue that explanation of power-sharing performance in new cases of consociation (as opposed to the classic cases investigated by Lijphart) requires consideration of the external dimension, the security dimension, and the self-determination dimension (McGarry, 2019). Given the reality of power-sharing performance problems, we need to better understand why such arrangements encounter governance difficulties when elites agreed to share power as the best compromise to achieve their respective groups' constitutional preferences. Why is power-sharing prone to governance crises despite the groups' willingness to end the conflict and share power?

To address this puzzle, we investigate the link between 'adoptability' (the extent to which the groups support the establishment of a power-sharing polity) and the 'functionality' of power sharing. The ever-expanding scholarship on power sharing has largely focused on functionality, the question of 'what works', often focusing on the effect of institutional rules and the distinction between corporate and liberal consociation. This research has been helpful 
in evaluating the variable effects of institutional rules with recommendations to policymakers to establish liberal consociational institutions (McGarry and O'Leary, 2007; McCulloch, 2014). There has been less focus on the 'adoption question', exploring the conditions under which groups agree to share power (Horowitz, 2014; McGarry, 2017). This concern for identifying the conditions in which power sharing is adopted has shifted to a focus on 'adoptability', i.e. the prospects of power-sharing arrangements being acceptable to the contending groups (McGarry, 2017).

We contend there is a crucial link between 'adoptability' and the functionality of powersharing. A fuller appreciation of this link will help inform debates on what makes for stable and effective power-sharing democracy. The article proceeds by discussing the literature on power sharing, honing in on the need to pay greater attention to the adoptability question. We then turn to Iraq to investigate whether the operational problems in the post-2005 political system can be explained by weak adoptability of the institutions. With evidence drawn from the existing literature and documentary research (media, policy documents, think tank reports), we argue that the challenges of power-sharing are aggravated when the specifics of the settlement are not sufficiently viewed as 'adoptable' by the respective groups. We point to several key reasons why a group is unlikely to view power sharing as adoptable. In Iraq, weak adoptability can be explained by three principal factors: Sunni boycott of the January 2005 elections and exclusion from the constitution-making process; the provision of a communal veto in the 2005 constitutional referendum that served the Shiite and Kurd communities but less so the Sunnis; and the US-imposed policy of de-Ba'athification. Together, these factors constrained the extent to which the constitutional settlement was supported by the Sunni population. Inferring from this case, we then argue that weak adoptability impacts on the functionality of power sharing in several ways. First, weak adoptability on the part of a main group can lead to that group's further exclusion and potential mobilisation against the state with severe consequences for governance and security. Second, weak adoptability on the part of one or more groups provides for the dominance of another group in politics, undermining the very basis of post-conflict power sharing. Third, weak adoptability serves to highlight unresolved contestation over the configuration of the state, potentially ratcheting up divergent constitutional claims over time. In such contexts, power sharing will flounder, leading to ongoing instability and the risk of renewed conflict.

\section{The Process of Power Sharing: From Adoptability to Functionality}


For academic advocates of power-sharing, institutional design ought to be fully inclusive of the main groups in society. An accommodationist strategy for managing diversity, powersharing seeks to ensure that each group 'has the public space necessary for it to express its identity, to protect itself against tyranny by the majority, and to make its own decisions in domains of critical importance' (McGarry, O’Leary and Simeon, 2008, p. 42). By virtue of such institutional rules designed to protect group identity and cultural autonomy, the contending groups are incentivized to engage in the political process and abandon violence. Power-sharing settlements are, therefore, more likely to be accepted by the contending groups (Walter, 2002) and act as a 'fear-reducing provision' to mitigate groups' commitment problems (Mattes and Savun, 2009). In states that have experienced civil war, power-sharing is argued to help address the sense of insecurity felt by belligerents, encouraging leaders and their supporters to engage in the electoral process, and thereby assist in the transition to democracy (Hartzell and Hoddie, 2015). Once established, power-sharing is argued to help stabilize such transitions to peace, accommodating group divisions by democratic means and promoting elite cooperation in government (McGarry and O'Leary, 2009; Wolff, 2011; McCulloch, 2014; McEvoy, 2015). Drawing on such expectations that power-sharing will help facilitate peace and democracy after conflict, international mediators increasingly recommend power-sharing as the best way to accommodate groups' competing self-determination claims and put an end to violence (Sisk, 1996; McCulloch and McEvoy, 2018).

In addition to ongoing debates regarding the performance or 'functionality' of powersharing, more research is needed to address what Horowitz (2014) terms the 'adoption problem' whereby little is known about the conditions under which power sharing can be adopted. The divergent preferences between a majority group (who will likely prefer majoritarian institutions) and a minority group (who will want a fully inclusive consociation) means that reaching an agreement will be difficult, potentially prolonging the conflict. Horowitz's notion of 'the adoption problem' has more recently been extended to the concept of 'adoptability' as referring to the prospects of specific institutional arrangements being acceptable to the main communities 'rather than the prospects of these institutions being “adopted," i.e., put in place' (McGarry, 2017, p. 17). Adoptability is therefore understood as 'a prerequisite for adoption' and that beyond agreement on the details of power sharing, settlements require 'motivational elements' such as 'external pressures, demographic change, economic opportunities or hurting stalemates' (McGarry, 2017, p.17). As Allison McCulloch puts it, 'it hardly matters whether an institution is functional if it cannot be agreed' $(2017$, p. 8). 
The issue of power-sharing 'adoptability' raises the question of how we can be sure that the settlement is acceptable to the groups. Given the hope that political leaders will help deliver peace, we rely on elites to reach an agreement. As in the case of Northern Ireland, the presence of brokers (cross-communal elites who build a winning coalition for a settlement and marginalize spoilers) can help legitimate the deal (Goddard, 2012). In addition to the expectation that elites will seek to 'sell' the deal to their respective communities, there is also an increasing emphasis on public endorsement of a new constitutional order via referendum. Some research has explored the extent to which peace/constitutional referendums provide an appropriate mechanism for groups to express their consent to the new political system. Yet debate continues on the relative merits and risks of employing direct democracy in deeply divided societies. For some, the zero-sum result of a referendum risks inflaming the conflict (Mac Ginty, 2003; Reilly, 2003; Lee and Mac Ginty, 2012). For others, the referendum has the potential to result in peaceful outcomes, particularly when groups agree to hold a referendum and the international community accepts the result (Qvortrup, 2014). A referendum held early on in the process, in advance of a settlement, can help negotiating elites shore up their credibility and mandate to do a deal (Loizides, 2014). The referendum may hold particular value in peace processes in facilitating "the "voice" of groups in such a way that they share constitutional authorship of the deal to transition to power-sharing, thereby enhancing legitimacy' (McEvoy, 2018, p. 866). The extent of 'adoptability' would otherwise become apparent by the parties' relative support in parliamentary elections. Challenges arise when groups have variable support for the deal, particularly when a group has grave reservations about the settlement and rejects it at the polls.

We conceptualize weak adoptability as occurring when one or more groups have less than majority support for the deal. We suggest that the adoptability of a settlement requires solid support from the respective groups, ideally with majority support expressed for parties in elections or popular vote in a referendum. Less than majority support on the part of one or more groups will mean weak adoptability and the likelihood of serious problems for implementation. Though adoptability is not necessarily fixed (i.e. some groups' support may increase over time and other groups' previous support may decrease or fall away), we contend it is important to ensure strong adoptability in the form of majority support from all groups at the point of creation and early implementation of the new arrangements. Such support will arguably enhance the legitimacy of the settlement and prospects for stability.

The overall aim of our article is to explore the effects of weak power-sharing adoptability on its functionality. As McCulloch and Vandeginste write, much scholarly 
attention is paid to the functionality of consociational arrangements 'which considers how functionality works, whether they work as intended, and whether they facilitate elite cooperation' (2019, p.1178). They suggest that the 'central critique of consociational functionality is its alleged tendency for immobilism' given the propensity of elites to position themselves as the true leaders of their respective groups, thereby adopting more hardline, less conciliatory politics (2019, p.1179). More general dictionary definitions of functionality refer to 'the quality or state of being functional' (Merriam-Webster). And synonyms of functionality include performance, purpose, service, and use. We can infer, then, that power-sharing functionality means the utility of the particular political system to secure the goals of elite cooperation and joint decision-making. A functional power-sharing system is one that proves useful for its intended purpose, ostensibly to promote elite cooperation, help the state transition to democracy, and secure peace. No mean feat for a set of fledgling political institutions in a deeply divided, war-torn society that may have little or no experience of democracy.

These conceptual arguments pertaining to the adoption process, the adoptability of power-sharing for groups and power-sharing functionality bring us to the Iraq case. The case clearly demonstrates that limited adoptability (whereby one or more groups view the powersharing arrangements as unacceptable) will have adverse implications for the functionality of power sharing. In the next section, we explore three problems in the power-sharing 'adoption process' in Iraq that explain the weak adoptability of power sharing. In the following section, we analyse the impact of these power-sharing adoption problems on the functioning of the power-sharing institutions. Ultimately, we show that weak adoptability can be explained by several factors largely pertaining to the exclusion of a main group, and that weak adoptability will increase the likelihood of political instability and conflict. Adoptability, then, is a central part of the power-sharing puzzle in deeply divided states transitioning from violent conflict.

\section{Iraq: Explaining Power-Sharing Adoptability Problems}

Political power-sharing was a key part of the Iraqi constitution approved in a referendum held on 15 October 2005. Iraq's version of power-sharing has been described as a case of consociationalism 'light' whereby the 2005 constitution 'suffers from a lack of durable national power sharing, a pre-occupation with self-rule at the expense of shared rule, and an experiment with..."fluid federalism"” (Bogaards, 2019, p.2). Due to a mix of institutional and political problems, the new system failed to herald a new era of peace and stability. On the contrary, Iraq witnessed a Sunni-Shiite civil war from 2006 to 2008, an attempt by Islamic State to 
establish a Caliphate in the Sunni-dominated west, and a secession attempt by the Kurdistan Regional Government (KRG) in the 2017 independence referendum. The ongoing violence, the independence bid by the KRG, and years of difficult relations between the governing parties in Baghdad, and between Baghdad and Erbil, highlighted the fragile functionality of the power sharing system. So how might a focus on adoptability help explain this outcome? We detect three problems with the adoption of power-sharing in Iraq that help explain weak adoptability: the marginalization of Sunni community during the elections of January 2005 and the subsequent process of constitution-making; the introduction of a de facto Shiite and Kurdish veto in the constitutional referendum rules while denying a Sunni veto; and the policy of deba athification.

\section{Sunni Exclusion: The January 2005 Elections and the Constitution-Making Process}

Iraq's first free and fair elections were held on 30 January 2005. The aim of the elections was to create a Temporary National Assembly (TNA) that would form a committee responsible for drafting the constitution. The beginnings of this process were unsurprisingly thwarted by intercommunal tensions, particularly as the Sunni community opted to boycott the elections. In the aftermath of the US-led invasion, Sunni leaders were mistrustful of their chances for fair representation under a single constituency electoral system 'which was likely to lead to the under-representation of provinces [and] where security concerns would prevent voters from getting to the polls' (Papagianni, 2007, p. 265). ${ }^{1}$ Instead, Sunni elites proposed the postponement of the elections and a new electoral law based on 18 districts in a PR system (Papagianni, 2007). As elections nevertheless took place under the single constituency PR system, Sunni elites boycotted the process, leading to extremely low voter turnout from their community. As a result of the boycott, only 17 Sunni-Arabs were elected to the national assembly (out of 275 members) (Arato, 2009, p. 211). Former US Ambassador to Iraq Zalmay Khalilzad noted the 'catastrophic consequences' from the 'failure to achieve broad-based participation in the election', leading ultimately to 'polarization and escalating sectarian violence' (Khalilzad, 2010, p.46). This crucial political step of holding elections to an assembly

\footnotetext{
${ }^{1}$ The decision to opt for a single constituency system (rather than multiple districts/provinces) was taken by CPA Director L. Paul Bremer in August 2004, reportedly on the advice of the UN's Electoral Assistance Division (Rubin, 2008). According to the New York Times, officials advised that the decision 'was driven by an unstable Iraq and the unrelenting pressure to speed the country to a vote' (See Weisman, 2005).
} 
that would in turn establish a committee to draft the constitution had an inauspicious start given the lack of Sunni representation.

The under-representation of the Sunni community in the TNA meant that the constitution-drafting committee set up in June 2005, with only two Sunni members out of a total 55, proceeded with negligible input from that group (Mosher and Fekeiki, 2005; al-Ali, 2014, p.85). Fifteen members from the Sunni community were added in July with full voting rights, and 10 additional Sunni members were assigned an advisory, non-voting status (Papagianni, 2007). These members were added due to American pressure in an attempt to make the process of drafting a new constitution more inclusive and legitimate (Glanz, 2005). ${ }^{2}$ Yet Sunni inclusion in the constitution-drafting committee was politically controversial for that community. Three Sunni members of the constitutional committee and one advisor were killed in the process (Jawad, 2013, p. 11). Moreover, the period during which Sunnis could effectively participate in the committee preparations was brief: the newly added Sunni members participated on 8 July, little over a month before the deadline of 15 August 2005 (Morrow, 2005, p. 9). Despite efforts to create a more inclusive committee, agreement between the parties remained elusive by the August deadline and responsibility for agreeing a draft constitution was passed to an ad hoc committee (Morrow, 2005, p. 9). But this new committee, referred to as the leadership committee/council, was led by deliberations between the Shiite and Kurdish elites (Al-Ali, 2014; Morrow, 2005; Papagianni, 2007). ${ }^{3}$ Though Sunni members reportedly requested to attend, the meetings held at irregular intervals at private residencies in the International Zone took place without them (Morrow, 2005, p.9). When it came to a decision on the draft constitution, the TNA adopted the text on 23 August without a vote. ${ }^{4}$ The absence of a vote in the Council of Representatives with respect to the proposed constitutional draft was due to three main reasons: first, the Americans wanted to complete the constitutional process to demonstrate to its audiences at home and abroad that it succeeded in transitioning

\footnotetext{
${ }^{2}$ With Grand Ayatollah Ali Sistani repeatedly calling for an inclusive process, the Bush administration chose and added the Sunni members. There was some controversy regarding the representativeness of these Sunni members, with some claiming they were too close to the Baath Party interests (see International Crisis Group, 2005, pp.2-3).

${ }^{3}$ The Leadership Council included leader of the Supreme Council for Islamic Revolution in Iraq (SCIRI) Ammar al-Hakim and Da'wa party leader Ibrahim al-Jaadari (both Shiite), leader of the Kurdish PUK Jalal Talbani and Kurdish KDP party leader Masoud Barzani. See Morrow, 2005.

${ }^{4}$ There was considerable inter-elite disagreement on the text and the process, largely owing to the pressure to complete the draft in August 2005. Having failed to meet the deadline of 15 August, Shiite and Kurdish elites agreed on a text on 28 August despite objections from Sunnis who withdrew from the negotiations. Tinkering with the text by Shiite and Kurdish negotiators continued in the following weeks with a 'final draft' presented to the TNA on 23 September (see International Crisis Group, 2005).
} 
Iraq into a democracy; second, the Americans wanted to avoid any objection to the draft constitution that would threaten this process; and third, any objection to the draft was to be left to the vagaries of the constitutional referendum.

Despite strong objections from Sunni elites, Shiite and Kurdish leaders moved forward with the draft constitution to be ratified by the wider population in a referendum. Faced with the fait accompli of the agreed draft constitution, Sunni representatives then withdrew from the process and vowed to bring down the constitution in the referendum (Ismael and Ismael, 2015, p.66). In addition to their removal from power in the aftermath of the US-led invasion, and fear of their future position in the state, Sunni marginalization in the period from the January 2005 elections to the October referendum hampered the extent to which that community was prepared to approve the constitution. This period of Sunni marginalization thus created the foundations for the weak adoptability of the new constitution.

\section{The Constitutional Referendum and Veto Rules}

With the Sunni community largely excluded from the constitution-making process, the package was essentially a set of trade-offs between the Shiites and the Kurds, whereby the Shiites secured the Islamic nature of the state as a whole and the Kurds legitimized their autonomy status (Anderson, 2015, p.83). An attempt was made to address Sunni grievances in preparation for the constitutional referendum, whereby drafters inserted Article 142 to establish a constitutional review committee. Article 142 provided for this committee to be composed of the principal groups with a remit to submit recommendations on constitutional amendments to parliament, which in turn would vote on the proposals (Hamoudi, 2014, p.2). For the US mediators, the insertion of Article 142 was designed to limit Sunni opposition and see off potential rejection (Jawad, 2013, p. 13). Article 142 was reportedly agreed just a few days before the referendum, as a 'last-minute compromise' (Morrow, 2006). US Ambassador Khalilzad sought to encourage Sunni support by stating that future reform under Article 142 would help secure the constitution 'as a national compact' and a 'living document' (in Morrow, 2006). With pressure from the US, the Islamic Party advised the Sunni community to approve the constitution in the referendum, a move that was rejected by other Sunni elites (Arato, 2009, p. 244; Jawad, 2013, p. 19). Thus, it can be argued that the insertion of Article 142 in the run up to the referendum did little to temper Sunni disillusionment with the constitution-making process. 
The design of the constitutional referendum, particularly the veto rules, was particularly contentious for Sunni elites. Under the Transitional Administrative Law (TAL), the interim constitution imposed by the Coalition Provisional Authority (CPA) in March 2004, Art. 61(c) provided that the constitution must be ratified with the support of a majority and should not be opposed by two-thirds of voters in any three of the eighteen governorates (TAL, 2004). The final text on ratification in the TAL was reportedly the result of a compromise between the Kurdish push for the permanent constitution to require majority approval in the Kurdistan region and an alternative proposal for ratification by a simple majority of citizens (McEvoy, 2018, p. 873). As Eklund, O'Leary and Williams write, the ratification of the constitution under Article 61(c) adhered to a 'federalizing logic' requiring a qualified majority whereby 'at least one third of voters in each of sixteen of Iraq's former eighteen governorates endorse the final constitution' (2005, pp. 119-120). This federal ratification rule would ensure that ratification had 'a high threshold of popular support and widespread territorial endorsement' (Eklund, O'Leary and Williams, 2005, p. 120). Thus, it was anticipated that the referendum rules would provide all locally concentrated majorities in Iraq (Shiites, Sunnis and Kurds) with a de facto veto over ratification of the constitution. Though the Sunni negotiators reportedly first accepted the rule as a potential means to limit Shiite power, the application of the rule was ultimately problematic. First, it was perceived by Sunnis that Article 61(c) had been tailored to the best interest of the Kurds and Shiites because they each formed an overwhelming majority in at least three governorates (Allawi, 2008, p. 223). Hence, it was perceived by Sunnis to be relatively easy for Kurds and Shiites to mobilize the required numbers to veto. On the contrary, it was known that the Sunni community formed a majority in only two of Iraq's governorates (Anbar and Salahuddin) and a slimmer majority in Nineveh and Diyala; they were apparently denied the same opportunity to veto the constitution (See Arato, 2009; Gaub, 2017). ${ }^{5}$

An additional problem relating to the constitutional referendum was that Iraq continued to face ongoing violence during the constitution-making process. In this environment, group identities increasingly crystallized according to religious belonging (Shiite/Sunni) or ethnonational identification (Arab/Kurdish) (Haddad, 2013). The conflict came to be framed in aggressively divisive sectarian terms' (Dodge, 2014, p. 15). In a country that failed to create

\footnotetext{
${ }^{5}$ Arato suggests that had the rules allowed for a simple majority in three governorates to reject the constitution, that provision would have been a clear veto for Sunnis. He writes that requiring a two-thirds qualified majority was very difficult for Sunnis to achieve in Nineveh, given the presence of a large Kurdish minority and that part of the province was administered by the Kurdistan Regional Government. See Arato, 2009, p. 322, note 129.
} 
an overarching national identity, sub-national groups continue to contest their vision of the Iraqi state. This form of contestation can be of ethnic nature, Arab vs. Kurds, or sectarian, Sunnis vs. Shia (Dawisha, 1999, p.554). In the context of this ongoing violence, the lack of Sunni involvement in the constitution-making process, and the controversy over the ratification rules, the Sunni community rejected the constitution overwhelmingly at the polls: the Sunni provinces of Anbar and Salahuddin had a 97 percent and 82 percent 'no' vote respectively, while Nineveh (a mixed governorate with a Sunni plurality and Kurdish minority) had a 55 percent 'no' vote, just 11 percent short of a two-thirds majority. Thus, the constitution was ratified by 80 per cent overall but came close to a Sunni veto short of just 11 per cent in one governorate. Rejection of the constitution was also significant in other governorates with substantial Sunnis numbers: in Diyala, 48 percent voted 'no', in Baghdad and Kirkuk 22 percent and 37 percent voted 'no' respectively (BBC, 2005). ${ }^{6}$ Though the referendum secured the necessary threshold for approval given the overwhelming support of the Shiites and Kurds, the constitution nevertheless failed to secure a wide-ranging consensus on the country's future. The lack of Sunni support and the controversy over the referendum rules (i.e. the uncertainty whether the rules denied the Sunni community their opposition to the constitution) further cemented the weak adoptability of the new political system.

\section{De-ba'athification}

A third principal factor explaining weak adoptability on the part of Sunnis to the new constitutional order lies in the policy of de-ba'athification. Established under Order No.1 of the CPA in May 2003, the policy barred from government work officials who ranked in the top four levels of the Baath party. Order No. 2 dissolved Iraq's 500,000 strong armed forces and intelligence services (Osman, 2015, p. 129; Aboultaif, 2015, p. 5). The CPA Orders on deba'athification have been subject to considerable criticism by academics and policymakers. To Sunnis, the CPA orders were understood as an explicit 'de-Sunnification process' (Keskin Zeren 2017, p. 66). The first decision had significant implications for post-war governance given that it 'effectively eliminated the leadership and top technical capacity' in the public sector (Pfiffner, 2010, p. 79). The CPA's second order on de-ba'athification, disbanding the Iraqi army, meant that hundreds of thousands found themselves out of work, creating 'a large

\footnotetext{
${ }^{6}$ See map for the demography of each province: http://gulf2000.columbia.edu/images/maps/Iraq_Ethnic_Shift_1947-2017_lg.png; http://3.bp.blogspot.com/GWoUG_3hfs8/UCeUd-OgHql/AAAAAAAAAKc/AWeXIyUP1h8/s1600/2005.jpg
} 
pool of unemployed and armed men who felt humiliated and hostile to the US occupiers' (Pfiffner, 2010, p. 80; Barakat, 2005). Dismantling the army has been described as 'the most disastrous mistake of the US administration' (Barakat, 2005, p. 579). Disbanding an army of 500,000 men, preventing them from being re-integrated into a reformed armed force or having the opportunity to work in the state sector ultimately contributed to the upsurge in violence against the Iraqi government and the US (Isakhan, 2015, p.23).

Though the CPA's policy of de-ba'athification was aimed at removing Saddam's loyalists from state institutions, it was viewed by Sunnis as a tool of persecution. As determining who was and who was not Baathist was based on personal judgement, the process became extremely controversial (Younis, 2011, p. 9). The difficulty in determining Baath membership was compounded by implementation problems, largely owing to the lack of detail on the criteria for identifying individuals. As Aysegul Keskin Zeren notes, the lack of criteria in determining 'the targets of de-Ba'athification and the assumption of collective responsibility led to an arbitrary implementation' (2017, p. 68). The lack of criteria and the speed with which the decisions were imposed also 'resulted in the purging nets being cast too widely' (Hatch, 2005, p. 105). Moreover, the lack of transparent reporting of who was dismissed for Ba'ath connections made it difficult to track the number of dismissed personnel (Sissons and al-Saiedi, 2013, p. 21). The number of civil servants dismissed due to de-Ba thification reportedly range from 900,000 to a million (Sissons and al-Saiedi, 2013, p.22). Though CPA head Paul Bremer allowed for consideration of appeals to allow party members to return to their posts, such decisions were tightly controlled by the US.

In an effort to transfer the responsibility for identifying Ba'ath Party members to Iraqis, the CPA set up the De-Ba'athification Council, led by Ahmad Chalabi, a well-known antiBa'ath Shiite politician who, as described by former US Ambassador to Iraq Ryan Crocker, used the policy 'as a political weapon' (Rubin, 2015; Hatch, 2005). Chalabi later acknowledged that although de-ba'athification which was meant to 'dismantle Baath Party control', the process was not meant to 'affect the overwhelming majority of Baathists.' With the benefit of hindsight, Chalabi acknowledged that the post-war process was hampered by Sunni exclusion: 'What happened in Iraq confirms that no single party can control the country's path. No important party in Iraq should ever feel that it is marginalized' (cited in Rubin, 2015).

In tandem with their exclusion from the constitution-making process and inability to veto the constitution, de-ba'athification further alienated the Sunni community from the 
political process and cemented their rejection of the new constitutional arrangements. Unsurprisingly, de-ba'athification exacerbated divisions between Sunnis and Shiites, escalating tension and division between the two groups. De-ba'athification served to fuel the emerging Sunni insurgency: by alienating thousands of Iraqis who could no longer support their families; by weakening state infrastructure; and by drastically reducing the security sector, thereby pushing trained and disgruntled officials and soldiers to take action against the US occupation and the state (Pfiffner, 2010). Against such a backdrop of perceived discrimination and alienation of Sunnis and increased violence, the adoptability of the new constitution was severely curtailed.

These three drawbacks (Sunni exclusion from the constitution-making process; unequal veto power; and the policy of de-ba'athification) help explain why there was little prospect of the new system being acceptable to Sunnis. In addition, the process was rushed and incomplete. Within months, the CPA had run elections for the first time in Iraq's history, pressured elites to agree on a constitution, and held a referendum, a brief period in which to draft and implement a constitution for a country with a history of conflict and no prior experience of democracy. Compare this process to Lebanon, for example, where the adoption of the Taif Accord took 15 years of proposals by different communities and parties until the agreement was reached. In Iraq, the first elections were boycotted by Sunnis, their eventual inclusion in the constitution drafting committee had little consequence and they were marginalized from the leadership council that arrived at a final text to be approved in the referendum. Overall, the Sunni experience of the constitution-making process did not bode well for the smooth implementation of the new political system.

\section{Impact of Weak Adoptability on Power-Sharing Functionality}

In this section we demonstrate that the weak adoptability of the new system impacted adversely on its functionality in several ways. First, the marginalization of Sunnis played an important role in the radicalization and militarization of the community, leading to the civil war 20062008. Second, weak adoptability provided political space for the dominance of Shiite elites, an opportunity harnessed by Prime Minister Nouri al-Maliki as he sought to concentrate power in his own hands, usurping control of the security sector and blocking administrative reform. Maliki's increasing hold on power exacerbated already difficult relations between Erbil and Baghdad, further fuelled by dispute over the KRG's share of the budget and distribution of oil 
revenues. Third, the weak adoptability of the new system served to highlight the ongoing contestation over the configuration of the state, exemplified by the move by the KRG to hold an independence referendum in 2017.

\section{Sunni Marginalization, Radicalization and Militarization}

The weak adoptability of the new constitutional framework led to the ongoing marginalization and increased radicalization and militarization of the Sunni community. The Sunni insurgency that emerged in the wake of the US-led invasion in 2003 consisted of several groups, the principal actor being Al-Qaeda in Iraq (AQI) in operation by late 2004 (Hashim, 2014). The marginalization of the Sunni community during the constitution-drafting process provided an opportunity for AQI to radicalize many Sunnis and transform them into Islamic militants (Gatson, 2017). Arguably, the core of AQI's success lies in the US decision to disband Saddam's overwhelmingly Sunni army. Rather than integrating soldiers into a new army, the policy of de-ba'athification denied hundreds of thousands of Sunnis from working for the government in the military and civil sectors. In this context, AQI benefitted from Sunni exclusion, marginalization and disillusionment (Kaelin, 2014).

AQI's infiltration into Iraqi society resulted in a civil war between Sunnis and Shiites which ended following an unexpected strategy by the US, incorporating Sunni militants into the security payroll, and deploying them to fight AQI (McCary, 2009, p. 45). The US then moved to support the Sunni "Anbar Awakening" movement that played a critical role in fighting AQI, denying them safe havens in Anbar, and expelling them from the region. ${ }^{7}$ This military gamble was ultimately successful, encompassing 'an immense, multifaceted, military, political strategy' to defeat AQI, an organization that represented somewhat less of a challenge than the military threat of Islamic State to come (Stansfield, 2014, p. 1342). Arguably, the adoption of the new constitution despite objections from the Sunni community and the deba athification process helped create the conditions for the civil war that finally ended in 2008 following the re-integration of the Sunni community into the security sector. This political and security environment severely hampered the already fragile transition, given the difficulty of reconstructing Iraq in the midst of ongoing conflict (Barakat, 2005).

\footnotetext{
${ }^{7}$ The Anbar Awakening was a US organized campaign to wipe out al-Qaeda from the Sunni areas in Anbar region, by cooperating with Iraqi Sunni tribes (providing weapons and money).
} 
Despite the success of the Anbar Awakening in fighting AQI, the Iraqi government failed to integrate the Sunni population. For instance, the de-ba'athification committee disqualified 511 Sunni candidates from running in the general elections, on alleged links to the Ba'ath party (al-Ali, 2014, p. 125). On the security front, al-Maliki followed a reversal strategy when the US began withdrawing from the country in 2011. When several areas throughout Iraq mobilized in protest against the government, the Prime Minister and his allies responded with force. The government focused on breaking up protests held by Shiites loyal to Moqtada asSadr in Baghdad, and other protests in Sunni regions, where hundreds of demonstrators were detained and government troops raided groups suspected of organizing demonstrations (Rayburn, 2014, pp. 216-218). In some cases, the government response was met by violence on the part of demonstrators, leaving several dead (Namaa, 2013).

Following US withdrawal in December 2011, Maliki cracked down on Sunni elites, ordering the arrest of Vice President Tariq al-Hashimi on charges of running death squads and the interrogation of Finance Minister Rafi a-Issawi's 150 bodyguards on terrorism charges (Parker, 2012, p. 98; Salaheddin and Schreck, 2012). By sidelining influential Sunnis, the community perceived the system as against their interests and in favour of Shiites. Moreover, the political environment of Maliki's efforts to suppress Sunni political activism facilitated the emergence of ISIS as 'a new manifestation of Sunni militancy in Iraq' (Stansfield 2016, p. 147; Hashim, 2014). As Dodge notes, although AQI was defeated militarily owing to US-led counter-insurgency from 2007, "the "surge" did not tackle the underlying political dynamics that caused the Iraqi civil war' (2014, p. 16). These conditions of Sunni marginalization and radicalization provided further space for the emergent ISIS to become more powerful than AQI (Byman, 2013; Fantappie, 2013). The legacy of the civil war and the escalation of sectarian tensions, marked by Sunni demonstrations against the government, allowed ISIS to take advantage of the security vacuum, ultimately leading to their control of Mosul and proclamation of the Caliphate/Islamic State in 2014 (Stansfield, 2014).

\section{Shiite Dominance in Security and al-Maliki's Quest for Hegemony}

The marginalization of the Sunni community during the constitution-drafting process and their subsequent rejection of the permanent constitution, opened up space for Shiite political elites, particularly Maliki and his tight-knit circle, to dominate the new political system and to take control of the security sector. As the US military began its withdrawal by 2010, Maliki 
exploited the situation to establish hegemonic control. Maliki's efforts to amalgamate power during his two terms as prime minister (covering the period from 2006 to 2014) served to further cement the ongoing disenchantment on the part of both Sunnis and Kurds (Dodge, 2013, 2014; O’Driscoll, 2017; Romano, 2014; Stansfield, 2014). In this section, we review Maliki's efforts to control the security sector, a policy enabled by the weak adoptability of the new political system on the part of the Sunni community.

Before the US invasion in 2003, the Iraqi army was 375,000 strong, with more than 300,000 reserves (Byman, 2003, p. 58). The CPA quickly moved to disband the army and "deba 'thify" the system, preventing the majority of soldiers from seeking government posts. In the post-invasion period, the US sought to reform the Iraqi armed services, investing 24.5 billion dollars by 2011 (Special Inspector General for Iraq Reconstruction, 2011). Yet in June 2014, Mosul and other places in the Sunni dominated Anbar province fell, the Iraqi army disintegrated and had to be re-trained and re-structured by the US and its allies. This crisis was significant: even though the US had invested in establishing a reformed army, the Iraqi security forces could not protect the country from falling apart.

Once in power and taking advantage of the weak adoptability of the new constitutional order on the part of the Sunni community, Maliki moved to secure Shiite control of the security sector. Part of this control derives from the constitution whereby Article 176 stipulates: "the Prime Minister is the direct executive authority responsible for the general policy of the State and the commander in chief of the armed forces." Due to the understanding between communities that the Prime Minister should always be a Shiite, by de facto the Shiite community therefore controlled the security forces. Maliki exploited this prerogative and used the armed forces as a tool for suppression against his opponents, in particular the Sunni population.

From 2006, Maliki undermined the army's chain of command by tying senior commanders and paramilitary units to him personally (Dodge, 2013, p. 126). By obtaining the mobile numbers of commanders all over the country and issuing orders directly to them, Maliki circumvented the chain of command and made those units personally answerable to him (alAli, 2014, p. 131). He built a personal power base on the security establishment and went on to appoint personal allies in the security apparatus, while dismissing others at will (Younis 2011, pp. 5-8; al-Ali, 2014, p. 131). As Dodge notes, Maliki used two institutions, the Office of the Commander in Chief and Provincial Command Centres, to secure control of the Iraqi 
security services (2014, pp. 12-13). Provincial Command Centres were set up in areas across the south and central Iraq, bringing 'together the command and control of police and army under one general in each province', chosen by Maliki himself (Dodge, 2014, p. 13). By exerting direct influence over the armed forces, Maliki undermined the Ministry of Defence which is reserved for the Sunni community, and thereby further aggravated relations between the groups in government (al-Ali, 2014, p. 131). As O’Driscoll (2017, p. 322) writes, although Maliki's strategy made opposition difficult, it conversely 'weakened Iraq militarily, as his focus was on self-preservation' rather than stability.

Shiite dominance of security was further cemented, and also complicated, by Maliki's relations with militias. Following the victory of the Islamic Shiite Council of Iraq (ISCI) in the 2005 elections, the group managed to have Bayan Jabr appointed as Minister of Interior. Jabr was a senior member of the ISCI militia, the Badr Brigade, and his first initiative was the widespread dismissal of non-ISCI members in the police force and the hiring of Badr Brigade militia (Rathmel, 2007). Consequently, the police became an instrument under the control of the Shiite community and acted as a sectarian death squad, reportedly resorting to extrajudicial execution and torture, mainly against Sunnis. Later in 2006, Jawad al-Bolani served as Minister of Interior and oversaw sustained attempts to purge sectarian militias (overwhelmingly from the Shiite community) from the state police. More than 60,000 men were sacked, and the police force continued to be plagued by corruption and sectarianism (Dodge, 2013, pp. 125-126). As a result, the weak adoptability of the new system resulted in Shiite domination of the security services which were then used to suppress opponents, by resort to Article 76 and by infiltration of Shiite militia into policing.

The functionality of the political system was further constrained by the rise of militia groups in the fight against ISIS. In 2014, in the wake of the Iraqi Security Forces' failure to stop the ISIS advance, a number of substate armed groups formed as the Popular Mobilization Forces (PMF, known as Kuwāt al-Hashd al-Sha 'bi) (O'Driscoll and Van Zoonen, 2017). The PMF was created following the fatwa (religious ruling) of the Shiite cleric Ayatollah Ali asSistani, calling on the Shiite community to take up arms against ISIS (Vohra, 2017). PMF was supported by Iranian weapons and training (Vohra, 2017), and became a legal paramilitary unit after parliament passed a law legalizing its status as complementary to the army (Hameed, 2016). Though the PMF played an important role in the fight against ISIS, the rise of the militia groups undermined the state's grip on security. Several issues with the PMF served to thwart power-sharing functionality. First, though the PMF included a number of different groups, it 
was overwhelmingly Shiite, further marginalizing the Sunni community. Second, the PMF was legalized despite Sunni MPs boycotting the parliamentary debate (Hameed, 2016). Of the 327 members of parliament, 208 voted in favour (less than two-thirds). Usually in deeply divided societies, critical matters are decided by a two-thirds or double majority, providing groups with a form of veto power. Third, as external to the army, the PMF threatened to 'delegitimize the government and its security forces' encompassing multiple forces with 'rival nationalisms that go against Iraqi unity and threaten the territorial integrity of the state' (O'Driscoll and Van Zoonen, 2017, p. 36).

The balance of power between the Shiite, Sunni and Kurdish groups during the constitution-drafting process (including the weak adoptability on the part of Sunnis) gave an advantage to the Shiite majority in the subsequent functionality of the new political system. Pursuing a strategy of hegemonic control, Maliki's actions stymied any prospect for improved inter-communal relations and 'marginalised both Kurds and Sunnis politically to the extent of no return' (O'Driscoll 2017, p. 316). The marginalization of the once dominant Sunni community provided space for Shiite dominance of the political institutions, particularly the security sector. Marginalising both Sunnis and Kurds, Iraq increasingly became a failing state embroiled in conflict. Amid increasing conflict and the alienation of the Sunnis and Kurds, Maliki's centralistic tendencies further embedded power-sharing. This dysfunction was borne out in the ratcheting up of contestation over several aspects of the constitution.

\section{Constitutional Contestation}

Given the problematic beginnings of the post-2005 political system, power-sharing was characterised by a lack of inter-communal cooperation, stalemate and dysfunction. In this section we argue that an important impact of the weak adoptability of the new constitutional order precipitated the ratcheting up of contention regarding the implementation of controversial constitutional provisions. This contention focused on the issue of disputed territories (especially the status of Kirkuk), the issue of oil and gas revenue sharing, and the issue of autonomy of the regions.

A particularly thorny issue for inter-communal relations in post-war Iraq concerned the status of so-called 'disputed territories', areas of particular historical and symbolic importance for the Kurds. To set in motion a process to manage the issue, the CPA introduced Article 58 into the TAL, later incorporated into the constitution as Article 140, requiring the 
'normalisation' of the disputed territories (by addressing the Arabization of the areas during the Saddam regime), followed by a census and a referendum on constitutional status. Article 140 thus provided for a referendum in Kirkuk and other disputed territories by 31 December 2007.

Despite Maliki's promises, progress on the implementation of Article 140 was continually blocked. With ongoing standoff between Baghdad and Erbil, Kirkuk's status 'rapidly assumed a position of unparalleled prominence' in Iraq politics (Anderson and Stansfield 2009, p. 3). The failure to find a solution to the unresolved status of Kirkuk and other disputed territories drastically stymied the prospect of fostering a stable power-sharing system. By 2014, with the issue still not resolved, and against the backdrop of the ISIS offensive, KRG President Massoud Barzani tasked the Kurdistan National Assembly to start preparing for an independence referendum (Guardian, 2014). To counter the ISIS threat, the KRG moved its peshmerga forces into Kirkuk, bringing more of the disputed territories under its control. This military presence meant the KRG secured effective control of areas whose status would have been subject to the implementation of Article 140. For Kurdish elites, the ongoing political instability in Baghdad, the failure to secure the implementation of Article 140, and their control of these areas further pushed the KRG towards holding a referendum in September 2017 when 92 per cent of voters supported independence for Kurdistan (BBC, 2017a). We suggest that the weak adoptability of the new system, compounded by the ambiguity on contentious issues provided the political space for Shiite control and Maliki's refusal to compromise (O'Driscoll, 2017 , p. 320). The failure to deal with the problem fed into increased contention over the constitutional provision on disputed territories and the KRG's emboldened position to push for independence. This desire for independence was further instrumentalised by Barzani in an effort to consolidate power in the Kurdish region (O'Driscoll and Baser, 2019). Constitutional contention continued in the wake of the referendum as the Iraqi government, Supreme Court and the international community refused to recognise the vote (BBC, 2017b; O'Driscoll and Baser, 2019).

The dysfunctional system also brought to the fore considerable contention relating to the constitutional provisions on the control of oil and gas and revenue sharing. Article 112 of the Iraq constitution stipulates that 'The federal government, with the producing governorates and regional governments, shall undertake the management of oil and gas' but restricts this role to 'present fields.' Divergent readings of the constitutional provisions pertaining to oil and gas led to considerable acrimony between the Kurds and the Maliki-led governments. Kurdish 
control of oil fields and their own resources appeared to threaten Maliki's power (O'Driscoll 2017, p. 323). Following the failure to reach an agreement between Baghdad and Erbil on a federal hydrocarbon law, the KRG moved to pass their own legislation allowing for the making of contracts with international oil companies despite considerable opposition from Baghdad (see Gunter, 2011; Walsh, 2018, pp. 189-190).

The contention over oil and gas revenue sharing was not directly caused by the weak adoptability of the system owing to Sunni opposition. However, Sunni marginalisation and disaffection towards the new constitutional order provided space for Shiite dominance, instrumentalized by Maliki to declare the Kurds' oil deal illegal and to block the transfer of funds from the state budget to the KRG. Given that the issue centred on acrimony between Baghdad and Erbil, it is difficult to determine the extent to which the constitutional provisions on oil and gas shaped Sunni disenchantment with the new political system. Yet, the ongoing dispute between Baghdad and Erbil certainly limited the prospect of smooth functioning of the political system, further alienating the Sunni community. Had the KRG been able to pursue its constitutional right to oil exploration, greater political stability might have been possible. There is even a view that the constitutional provisions on oil and gas pushed many Sunnis towards insurgency. But had the constitutional provisions been implemented fully and in good faith, oil and gas revenues would have benefitted the general population in keeping with Article 111 that stipulates that 'oil and gas are owned by all the people of Iraq' and Article 112.1 which obliges the government to ensure that current revenues are 'distributed in a fair manner in proportion to the population distribution in all parts of the country...' (see McGarry and O'Leary, 2007, p. 685). The fair management of oil and gas revenues may have gone some way to alleviate Sunni disenchantment. This missed opportunity can be traced to the weak adoptability of the constitution, manipulated by Maliki's hegemonic control and led to increased contention over implementation of the constitutional provisions.

A related problem is that the constitution does not set out the distribution of the state budget between Baghdad and the regions. It is by agreement that the KRG receives 17 percent of the budget, in proportion to its population (Danilovich, 2014, p.127; Le Billon, 2015, p. 41). Moreover, the constitution does not oblige the KRG to make payments to Baghdad. Hence, the KRG tended not to make public its customs revenues or register complete documentation for its oil exports (Danilovich, 2015, p. 127). The absence of a clear clause in the constitution regarding the share of KRG's allocation from the budget allowed the central government to use it as a tool of political blackmailing. Weaponizing the budget was clear in 2013 when the KRG 
and Baghdad disagreed on their shares of oil from the co-managed fields in Kurdistan. There was a mismatch between the figures supplied by the KRG and the number apparently produced; Baghdad responded by cutting funds transferred to Erbil (Danilovich, 2015, p. 133).

Finally, we suggest that the weak adoptability of the new constitution served to ratchet up contestation over the rights of governorates to create additional regions within a federal Iraq. An important opportunity for regional autonomy was provided for in the constitution under Article 119: 'One or more governorates shall have the right to organize into a region based on a request to be voted on in a referendum' either by a request of at least one third of a governorate's council members or one tenth of voters in the governorate. It is reasonable to assume that these provisions did not entice Sunnis to support the constitution as they feared finding themselves in a state that benefitted the Shiites and Kurds at their expense. Yet, in the context of ongoing instability and Maliki's efforts to centralise governance at the expense of Sunnis and Kurds, the previously dominant group was increasingly drawn to the potential of creating their own region (O’Driscoll, 2017). For example, following protests and widespread arrests in Sunni areas in 2011, the Sunni-majority governorates of Salahdin and Diyala initiated the constitutional process to become a federal region (Rayburn, 2014, p. 220). In response, Maliki blocked the process, fearing that such a move would provide Sunnis with the opportunity to create an armed force similar to the Peshmerga, making it hard for Baghdad to contain the Sunni population. Maliki succeeded in blocking the process by pressuring the independent high electoral commission to ignore Sunni calls for a referendum. As O'Driscoll (2017, p. 328) notes, the paradoxical situation arose whereby Maliki's efforts to curb regional autonomy served to heighten demands on the part of the Kurds but also the Sunnis. Notably the creation of a Sunni region has been advocated as means to increase trust on the part of Sunnis and to provide them some protection (O'Driscoll, 2017), a move that arguably had potential to address the weak adoptability of the new constitution and enhance its legitimacy among Sunnis. Yet little changed in the years immediately following Maliki's tenure, as Prime Minister Haidar al-Abadi has not shown facilitated the Sunnis or Shiites of the south to form regions, further augmenting constitutional contestation.

\section{Conclusions}

The ever-growing literature on post-conflict power sharing has focused on the question of 'what works', that is, on the institutional rules that matter for power-sharing practice, often 
pitted as a choice between liberal and corporate consociation. In addition to this concern for power-sharing performance, there are arguably more foundational questions regarding the prospects for power-sharing adoptability, the extent to which contending groups view powersharing as a satisficing solution to their divergent constitutional preferences. In this article, we have explored the link between power-sharing adoptability and functionality. Drawing on the case of post-invasion Iraq, we have demonstrated that weak power-sharing adoptability on the part of one or more groups can have severe adverse consequences for the implementation and operation of post-conflict institutions. In this case, weak adoptability can be explained by Sunni marginalization in the constitution-making process, their inability to veto the draft constitution in the 2005 referendum, and the US-imposed policy of de-ba'athification. In turn, these problems that account for the weak adoptability of the constitutional package impacted on power-sharing in several ways. First, the adoption of the constitution despite Sunni objections led to the further marginalization and radicalization of that group. As witnessed during the Sunni-Shiite civil war (2006-2008), ongoing violent conflict posed a grave threat to communal relations and the operation of the power-sharing institutions. Second, Sunni rejection of the constitutional arrangements provided the conditions for Shiite elites to take control of the state, undermining any potential for inter-communal elite cooperation. Third, the limited adoptability of the power-sharing system for Sunnis further inflamed the contestation over the future configuration of the state, leading the KRG to take the opportunity to hold an independence referendum in September 2017. In the context of these serious challenges, power-sharing functionality was severely impaired.

It is also worth considering that a system established with only weak adoptability is likely to be hampered by a range of political problems. In Iraq, the new system failed to provide good governance for citizens and became increasingly stuck in a web of patronage and corruption. Citizens' frustrations at institutionalized corruption and governance failures manifested in the form of sporadic street protests, the most significant round of demonstrations took place from October 2019 with hundreds of lives lost to security forces (Fantappie 2019; Rubin 2019). Though the emergence of street protests may not seem directly related to weak adoptability of the power-sharing system, weak adoptability arguably provided the conditions for a narrow elite to engage in corruption and to neglect governance responsibilities relating to the provision of public services and economic growth.

The article's insights point to the importance of adoptability as a key concept for powersharing theory and practice. For power-sharing theory, we need to extend such analysis across a variety of case studies to determine the conditions in which power-sharing is viewed as 
'acceptable' for contending groups and is therefore more likely to be 'adoptable.' Powersharing theory also needs to better consider how questions of adoptability, in particular the likely variation of groups' support for power sharing, impacts on the operation of powersharing institutions once adopted.

In practical terms, these conceptual and empirical insights also have potential significance for third-party mediators engaged in peace negotiations and in constitutionmaking processes. Important lessons can be derived from the Iraq case, potentially transferable to other conflict-affected societies, which point to the need for widespread inclusion in constitutional design processes and for the need to create a process in which contending groups are sufficiently incentivized to support the deal. We suggest that a key concern for constitutional design processes must look beyond the exigency of reaching a settlement to thinking about the potential ramifications of weak adoptability on the implementation and functionality of the new system. To help increase the prospects of functionality, the adoptability process should be fully inclusive, respecting the respective groups' vital interests and taking into consideration groups' perceptions of the settlement as an existential threat to their survival. The repercussions of imbalanced power-sharing adoptability (when groups have considerably divergent levels of support for the deal) may prove insightful for other cases where powersharing has been debated as a potentially feasible institutional prescription including Libya, Myanmar, Syria and Yemen.

\section{References}

Aboultaif, E. W. (2015). The Limitations of the Consociational Arrangements in Iraq. Ethnopolitics Papers(38), 1-22.

al-Ali, Z. (2014). The Struggle for Iraq's Future: How Corruption, Incompetence and Sectarianism Have Undermined Democracy. New Haven: Yale University Press.

al-Khalidi, Z. M. (2014, August 5). How Big of a Loss is Kirkuk's Oil for Baghdad? al-Monitor. Retrieved December 1, 2017, from https://www.al-monitor.com/pulse/security/2014/08/kirkuk-kurdistanregion-oil-economy-iraq-government.html

Anderson, L. 8. (2015). The Dangerous Legacy of a Flawed Constitution: Resolving Iraq's Kurdish 'Problem. In B. Isakhan, The Legacy of Iraq: From the 2003 War to the Islamic State (pp. 82-96). Edinburgh: Edinburgh University Press.

Anderson, L., \& Stanfield, G. (2010). Avoiding Ethnic Conflict in Iraq: Some Lessons from the Alands Islands. Ethnopolitics, 9(2), 219-238. 
Bartu, P. (2010). Wrestling With the Integrity of a Nation: The Disputed Internal Boundaries in Iraq. International Affairs, 86(6), 1329-1343.

Bartu, P. (2010). Wrestling With the Integrity of a Nation: The Disputed Internal Boundaries in Iraq. International Affairs, 86(6), 1329-1343.

Bogaards, M. (2019) Iraq's Constitution of 2005: The Case Against Consociationalism 'Light'. Ethnopolitics, DOI: 10.1080/17449057.2019.1654200

Byman, D. L. (2003). Building the New Iraq: The Role of Intervening Forces. Survival: Global Politics and Strategy, 45(2), 57-71.

Byman, D. L. (2013). The Resurgence of Al Qaeda in Iraq. Brookings. Retrieved May 26, 2019, from https://www.brookings.edu/testimonies/the-resurgence-of-al-qaeda-in-iraq/

Danilovich, A. (2014). Iraqi Federalism and the Kurds: Learning to Live Together. New York: Routledge.

Dawisha, A. (1999). "Identity" and Political Survival in Saddam's Iraq. The Middle East Journal, 53(4), 553-567

Dodge, T. (2013). Iraq - from War to a New Authoritarianism. New York: Routledge.

Fantappie, M. (2013). Contested Consolidation of Power in Iraq. The Carnegie Papers. Retrieved May 26, 2019, from https://carnegieendowment.org/files/contested_consolidation.pdf

Fantappie, M. (2019). Widespread Protests Point to Iraq's Cycle of Social Crisis. Commentary. International Crisis Group. 10 October 2019. https://d2071andvip0wi.cloudfront.net/10-oct-10widespread-protests.pdf

Gaston, E. (2017). Sunni Tribal Forces. Global Public Policy Institute. Retrieved February 27, 2019, from https://www.gppi.net/2017/08/30/sunni-tribal-forces

Glanz, J. (2005, August 25). Sunnis on Constitutional Panel: Determined but Impugned. The New York Times. Retrieved January 10, 2020, from

https://www.nytimes.com/2005/08/25/world/middleeast/sunnis-on-constitution-paneldetermined-but-impugned.html

Hameed, S. (2016, November 26). Iraqi Parliament Passes Contested Law on Shi'ite Paramilitaries. Reuters. Retrieved May 26, 2019, from https://www.reuters.com/article/us-mideast-crisis-iraqmilitary/iraqi-parliament-passes-contested-law-on-shiite-paramilitaries-idUSKBN13LOIE

Hamoudi, H. A. (2014). Negotiating in Civil Conflict: Constitutional Construction and Imperfect Bargaining in Iraq. Chicago: The University of Chicago Press.

International Crisis Group. (2005). Unmaking Iraq: A Constitutional Process Gone Awry. Middle East Briefing No.19. Brussels, 26 September 2005.

Iraq Voters Back New Constitution. (2005, October 25). BBC. Retrieved December 5, 2017, from http://news.bbc.co.uk/2/hi/middle_east/4374822.stm

Isakhan, B. (2015). The De-Baathification of Post-2003 Iraq: Purging the Past for Political Power. In B. Isakhan, Legacy of Iraq: From the 2003 War to the Islamic State (pp. 21-35). Edinburgh: Edinburgh University Press. 
Kaelin, J. (2014, October 13). A Government For The People by The People: Defeating ISIL With an Inclusive Central Iraqi Government. Foreign Policy Journal.

Le Billon, P. (2015). The Contested Politics of Iraq's Oil Wealth. In B. Isakhan, Legacy of Iraq: from the 2003 War to the Islamic State (pp. 36-49). Edinburgh: Edinburgh University Press.

McCary, J. A. (2009). The Anbar Awakening: An Alliance of Incentives. The Washington Quarterly, 32(1), 43-59. Retrieved May 26, 2019, from https://csis-prod.s3.amazonaws.com/s3fs-

public/legacy_files/files/publication/twq09januarymccary.pdf

McCulloch, A., \& Vandeginste, S. (2019). Veto Power and Power-Sharing: Insights from Burundi (2000-2018). Democratization, 26(7), 1176-1193

McGarry, J., \& O'Leary, B. (2007). Iraq's Constitution of 2005: Liberal Consociation as Political Prescription. International Journal of Constitutional Law, 5(4), 670-698.

McGarry, J. (2019). Classical Consociational Theory and Recent Consociational Performance. Swiss Political Science Review, 25(4): 538-555.

McGarry, J. (2020). A Consociationalist Response. Ethnopolitics, 19(1), 100-106.

Morrow, J. (2005). Iraq's Constitutional Process II, An Opportunity Lost. Wahington DC: United States Institute for Peace.

Mosher, A., \& Omar Fekeiki, O. (2005, June 17). Sunnis Added to Iraq Constitution Panel. The Washington Post. Retrieved January 2, 2018, from http://www.washingtonpost.com/wpdyn/content/article/2005/06/16/AR2005061600529.html

Namaa, K. (2013, December 30). Fighting Erupts as Iraq Police Break Up Sunni Protest Camp. Reuters. Retrieved May 26, 2019, from https://www.reuters.com/article/us-iraq-violenceidUSBRE9BTOC620131230

Osman, K. F. (2015). Sectarianism in Iraq: the Making of State and Nation Since 1920. New York: Routledge.

Papagianni, K. (2007). State Building and Transitional Politics in Iraq: The Perils of a Top-down Transition. International Studies Perspectives, 8(3), 253-271.

Parker, N. (2012). The Iraq We Left Behind: Welcome to the World's Next Failed State. Foreign Affairs, 91(2).

Rathmell, A. (2007). Fixing Iraq's Internal Security Forces: Why is Reform of the Ministry of Interior so Hard? Washington: Center for Strategic and International Studies. Retrieved January 2, 2019, from http://iraqslogger.powweb.com/downloads/071113_fixingiraq.pdf

Rayburn, J. (2014). Iraq After America: Strongmen, Sectarians, Resistance. California: Hoover Institution Press.

Robertson, N., \& Formanek, I. ,. (2005, October 26). Iraqi Constitution Passes. CNN. Retrieved December 1, 2017, from http://edition.cnn.com/2005/WORLD/meast/10/25/iraq.constitution/

Rubin, M. (2008). Iraq's Electoral System: A Misguided Strategy. Carnegie Endowment for International Peace. Retireved 9 Januaru 2020, https://carnegieendowment.org/sada/21208 
Rubin, A.J. (2019). Iraq in Worst Political Crisis in Years as Death Toll Mounts from Protests. The New York Times. 21 December 2019

Salaheddin, S., \& Schreck, A. (2012, December 21). The Washington Post. Retrieved December 20, 2018, from https://www.washingtonpost.com/world/middle_east/iraq-confirms-arrest-of-ministersbodyguards/2012/12/21/df60b1c6-4b9f-11e2-9a42-

d1ce6d0ed278_story.html?utm_term=.18ef1d9b3e0e

Sissons, M., \& al-Saiedi, A. (2013). Iraq a Bitter Legacy: Lessons of De-Baathification in Iraq.

International Center for Transitional Justice. Retrieved May 26, 2019, from

https://www.ictj.org/sites/default/files/ICTJ-Report-Iraq-De-Baathification-2013-ENG.pdf

Special Inspector General for Iraq Reconstruction. (2011, July 30). Quarterly Report and Semiannual

Report to the United States Congress. Retrieved May 26, 2019, from

https://cybercemetery.unt.edu/archive/sigir/20131001094140/http://www.sigir.mil/files/quarterlyr eports/July2011/Report_-_July_2011.pdf\#view=fit

Vohra, A. (2017, October 18). “Iraq's Shiite Militias Are Just Getting Started. Foreign Policy. Retrieved January 1, 2017, from http://foreignpolicy.com/2017/10/18/iraqs-shiite-militias-are-just-gettingstarted/

Weisman, S.R. (2005). U.S. Is Haunted by Initial Plan for Iraq Voting. The New York Times. 9 January 2005. Retrieved 9 Jan 2020, https://www.nytimes.com/2005/01/09/world/middleeast/us-ishaunted-by-initial-plan-for-iraq-voting.html

Younis, N. (2011). Set Up to Fail: Consociational Political Structure in Post-War Iraq 2003-2010. Contemporary Arab Affairs, 4(1), 1-18.

Zeidel, R. (2015). Between Aqalliya and Mukawin: Understanding Sunni Political Attitudes in PostSaddam Iraq. In B. Isakhan, Legacy of Iraq: from the 2003 War to the Islamic State (pp. 97-109). Edinburgh: Edinburgh University Press. 